\title{
Protecting Consumer Medicine In Indonesia: Examining The Role of Pharmacist
}

\author{
Norma Sari \\ Law Faculty University of Ahmad Dahlan \\ Pramuka Street No 42 Yogyakarta \\ norma.sari@law.uad.ac.id
}

\begin{abstract}
Pharmacy as a profession has been undergoing many relevant changes in facing many challenges and social demands. The consumers generally are not well-acknowledged of many drugs to consume, to increase, or to maintain their health level. This research aims at understanding the role of a pharmacist in protecting the drug consumers in Indonesia. The reserach is a normative one relying on secondary data source. The data is collected by document study through reading, studying, and identifying the data to be analyzed qualitatively. The research result concludes that the pharmacists play an important role in protecting drug consumers in Indonesia by (1) being responsible in providing (a) quality assurance, production, quality control of pharmacy industry (b) pharmaceutical services in the public pharmacy. (2) Cutting off the edge business directly facing the drug/consumers in the long chain mechanism of drug consumption.
\end{abstract}

Keywords : Protection, consumer, Indonesia, role, pharmacist

\begin{abstract}
Abstrak
Profesi farmasi telah mengalami perubahan yang relevan dalam menanggapi tantangan dan kebutuhan sosial. Konsumen umumnya tidak menyadari banyak hal tentang obat yang harus dikonsumsi untuk meningkatkan atau mempertahankan kualitas kesehatan. Penelitian ini bertujuan untuk mengetahui bagaimana peran apoteker dalam melindungi konsumen obat di Indonesia. Penelitian ini merupakan penelitian normatif dengan sumber data sekunder. Metode pengumpulan data adalah studi dokumen, dengan membaca, mengkaji dan mengidentifikasi kemudian dianalisis secara kualitatif. Hasil penelitian menyimpulkan, peran apoteker untuk melindungi obat konsumen di Indonesia adalah (1) bertanggung jawab dalam menyediakan (a) jaminan kualitas, produksi dan kualitas kontrol pada industri farmasi (b) pelayanan farmasi di apotek umum (2) memotong bisnis tepi yang berhadapan langsung obat / dengan konsumen dalam mekanisme rantai panjang dari konsumsi obat.
\end{abstract}

Kata kunci : Perlindungan, konsumen, Indonesia, peran, apoteker 


\section{Background}

In the modern society, it is widely argued that while the role of pharmacist has grown uphis/herrational or clinically unjustified use of medicines is still a major problem worldwide including in Indonesia. World Health Organization (WHO) estimates that more than half of all medicines are prescribed, dispensed or sold inappropriately, and that half of all patients fail to take them correctly. The overuse, underuse or misuse of medicines results in wastage of scarce resources and widespread health hazards. Examples of irrational use of medicines include: use of too many medicines per patient (poly-pharmacy); inappropriate use of antimicrobials, often in inadequate dosage, for non-bacterial infections; over-use of injections when oral formulations would be more appropriate; failure to prescribe in accordance with clinical guidelines; inappropriate self-medication, often of prescription-only medicines; non-adherence to dosing regimes. ${ }^{1}$ In Indonesia, based in the report on the National Map of Patient Safety, released by Indonesian Hospital Association in 2007, it was said that the wrongdoing in prescribing drug was considered as the most frequent mistake or about $34 \%$ out of 10 other aspects. In more details, the number of wrongdoing in dispensing drug outnumbered other medication processes including prescribing, transcribing and administrating drugs. ${ }^{2}$

Healthy definition provided in Article 1 of Law No. 36 of 2009 on Health is good health, both physically, mentally, spiritually and socially to enable more people to live socially and economically productive.Health efforts are all activities to maintain and improve health, aiming to realize the degree of optimal health for the community. Health efforts organized approach to the maintenance, improvement health promotion, disease prevention preventive, curative cure disease and restore health rehabilitative, are implemented fully, integrated, and continuous. ${ }^{3}$ Modern drug therapy plays a crucial role in improving the health of people by enhancing quality of life and extending life expectancy. Importantly the

\footnotetext{
1 Indonesian Consumer Protection Foundation, Examining the National Drug Policy, 2012 http://ylki.or.id/2012/01/menelaah-kebijakan-obat-nasional/ accessed on 9 August 2014.

${ }^{2}$ Ministry of Health, Pharmacist Responsibilities of Patient Safety Directorate of Community Pharmacy and Clinical Pharmaceutical Development, 2008, page 11.

${ }^{3}$ Ministry of Health Decree No. 1197/Menkes/SK/X/2004
} 
study of drug advantages for maintaining health and wellbeing of human life is highly correlated with aspects of consumer protection laws. As shown in Indonesia's drug policy, the protection of consumer medicines especially in the case of non-branded generic drugs have not been described clearly that potentially his/her rights left uncovered by law. 4

\section{Statement of Problems}

From the background above, this research was conducted find out the description about how the role of pharmacist in protecting consumer medicine in Indonesia.

\section{Aim of Research}

According to the problem statement, the purpose of this research is to knowabout how the role of pharmacist in protecting consumer medicine in Indonesia

\section{Research Method}

This type of research a normative legal research with the descriptive study report. Descriptive means that the results are expected to give a comprehensive picture of the role of pharmacist in protecting consumer medicine in Indonesia. Data obtained from library research is secondary data derived from the Primary, Secondary and and Tertiary Law Materials. Data collection method is study of the document, by reading, reviewing and identifying systematically secondary data sources. All collected data will be analyzed data by qualitative descriptive, which is a way to draw conclusions provide an overview or outlines of the data collected

${ }^{4}$ Iwan Dwi Prahasto, Indonesian Drug Policies Are Still Not Favoring Patients: Examples of Generic Drugs, Policy Bries No. 10/August 2010, Health Services Management Centre Faculty of Medicine Gadjah Mada University, Yogyakarta, 2010. 
in the form of sentence description that could eventually deliver to the conclusion. ${ }^{5}$

\section{Discussion and Result}

\section{Pharmacist, Clinical Pharmacy and Pharmaceutical Care}

Pharmacist is a scholar who have graduated from the pharmacy profession academy and taken a vow by applicable legislation and entitled to work in Indonesia as a pharmacist. Pharmaceutical care is a form of direct service and professional responsibility of pharmacist in pharmacy to improve the quality of life of patients. Pharmacy work is the manufacture, processing, compounding, conversion forms, mixing, storage and delivery of a drug or medicinal substance. ${ }^{6}$ Additionally, pharmacist is obliged to provide adequate drug information for consumer as parts of her/his service. ${ }^{7}$

There are three stages of pharmacist roles in servicing the health needs of the society throughout the history. The first is called the Traditional Stage identified when the role of pharmacist was only procuring, preparing, and evaluating drug products. The primary duty was to ensure that the sale of medicine is pure, unadulterated, and prepared secundumartem (in pharmacy, preparations made secundum artem ensure they are pure and unadulterated, but the phrase also encompasses the apothecary's obligation to provide good advice to customers who request over the counter drugs $^{8}$ ), although they have a secondary obligation to provide good advice to customers who asked about the prescription of it. This traditional role had begun to wane as the preparation of medicines has been gradually taken over by the pharmaceutical industry and as the choice of therapeutic agents passed to the physicians. ${ }^{9}$

The next stage is the transition period in which pharmacist is obliged to perform new tasks in the pharmaceutical provision. The task was entitled to

${ }^{5}$ Abdulkadir Muhammad, Law and Law Research, Citra Aditya Bakti, Bandung, 2004 page 38.

${ }^{6}$ Act No. 7 of 1963 on Pharmacy, Article 2.

${ }^{7}$ Act No. 36 Year 2009 on Heatlh article 108.

${ }^{8}$ See http://www.usciences.edu/museum/secundum artem.shtml, accessed on 9 August 2014.

${ }^{9}$ Ernst FR, Grizzle AJ, Drug-related Morbidity and Mortality: Updating the Cost-ofillness Model. J Am Pharm Assoc 41, Washington, 2001, page 192-199. 
develop innovative role transformed by the advance of medical science with the rise of the clinical pharmacy. Medication was the ultimate goal and there was no patient approach. ${ }^{10} \mathrm{As}$ a consequence of the identification of the patient as the pharmaceutical care core, the transition period and clinical pharmacy evolved into a period directed to the patient and the pharmaceutical care. On this pharmacist paradigm change, medication is the mean to solve the patient health needs. Professional challenges arise at the political, economic and social levels, accompanied by the need to elaborate, promote and implement pharmaceutical policies that allow the global and national establishment of the pharmaceutical activity. ${ }^{11}$

In Indonesia, the role of pharmacistis explained by the Presidential Regulation No. 51 Year 2009 about the professional duties of pharmacist as listed below: a. responsible in providing quality assurance, production and quality control on the pharmaceutical industries; $b$. responsible in providing drug/pharmaceutical services in public pharmacies both in hospitals, local clinics, drugstores and other medical providers; c. rharmacist is allowed to replace branded drug with generic one with similar ingredients as agreed by General Practitioners, Specialists and/or patients' wishes; d. pharmacist is allowed to appoint assistant with Lisence to Practice Pharmacy qualification to fulfill his/her duties.

Moreover, according to the regulation issued by the Ministry of Health, Republic of Indonesia No. 1027/Menkes/SK/IX/2004 about the Standardized Pharmaceutical Services in the Pharmacies, pharmacist is obliged by three primary roles. The first one relates to the provision of prescription services that cover both screening by examining the administrative aspects of medicines and other clinical considerations, and preparing the medicines including its dispensing, packaging, providing information and consultation and monitoring drug uses. Second, pharmacistis supposed to promote and educate public regarding the proper drug user through leaflets, brochures and other media. Pharmacist should provide adequate information on how to use medicine to treat 
common illness experienced by patients. Third, pharmacist is obliged to provide home/residential care according to his/her role as care givers. They are supposed to visit the home of aged persons or patients with chronic situation. For the purpose of this duty, pharmacist must write such a medication record. Sufficed it to say, that pharmacies are regarded as one of the public health service directed to improve and optimize the health quality of the society and/or as a workplace for pharmacist to do his/her professional job. ${ }^{12}$

Rather different to the service in public pharmacies, the drug provision in the hospital has been regulated by the ordinance of the Ministry of Health, No. 1197/MENKES/SK/X/2004 regarding the Standardized Pharmaceutical Provision in the Hospital. The role of the pharmacist consists of two matters, (1) as pharmacist; and (2) members of committee on pharmacy and therapy. The former role obliges them to manage medicine supplies and pharmaceutical provision; while the latter leads them to involve in decision making regarding the drug policy and regulation throuhought the hospital.

The primary tenets in the provision of health services for patients include both the health and safety. In this regard, the role of pharmacist, either as individual or team, is addressed on ensuring the safety of the medication treatment. His/her role include providing a report of mistakes or failures in the medication treatment and identifying the process with a special purpose of ensuring its safety. Pharmacist is also entitled to educate medical/clinical staffs to perpetuate a safe medication treatment both for them and patients as well; and participate in the medical committee in regard of the issue of the safety of medical treatment, of the research and development of drug uses and monitoring the practices of the standardized safety regulation in treating patients. Additionally, pharmacist preserve the main role of improving the safety and the effectiveness of drug uses. They are entitled to ensure patients as the consumer medicines receiving the optimized medical treatment. To note, such an active involvement of

${ }^{12}$ Hartini YS and Sulasmono. Pharmacy: Review and Its Related Scripts Pharmacy Regulations Includes Manuscript and Review Minister of Health Decree About People's Pharmacy, University of Sanata Dharma, Yogyakarta, 2007 page 13. 
pharmacist is considered to contribute positively in reducing medication mistakes or mall-treatment. ${ }^{13}$

\section{Consumer, Business Actors and Consumer Medicine Protection}

Definition of consumer medicine are not specifically can be found in legislation and other legal sources. Referring to the definition of consumer listed in Act No. 8 of 1999 on Consumer Protection, consumer is every person user of goods and / or services available in the community, both for the benefit of herself, her family, other people and other living beings and not to be traded. ${ }^{14}$ The term is derived from the consumer rather than the word consumer language (AngloAmerican), or consument / konsument (Netherlands). Literally meaning the consumer is (as opposed to manufacturers) any person who uses goods. ${ }^{15}$

Consumer is not just buyer but all those (individuals or entities) that consume services and / or goods. So, the most important occurrence of a consumer transaction (consumer transactions) in the form of intermediate goods and / or services, including the transfer of enjoyment in using it. ${ }^{16}$ Analogously understanding of consumer medication is every drug user is available in the community, both for the benefit of himself/herself, his/her families, other people and other living beings and not for sale.

Consumer in interaction in the community are dealing with entrepreneurs (any individual or business entity), either in the form of legal entity or legal entity established and domiciled or conducting activities within the jurisdiction of the Republic of Indonesia, either itself or through joint agreements carrying on business in a variety of economics. ${ }^{17}$ According to consumer rights under Act No. 8 of 1999 on Consumer Protection are: a. right to comfort, security, and safety in consuming goodsand / or services; b. the right to choose the goods and / or services as well as goods and / or servicesaccordance with the exchange rate and the conditions and guarantees promised; c. right to information is correct, clear,

\footnotetext{
13 Ministry of Health,Pharmacist Responsibilities of Patient Safety, Directorate of Community Pharmacy and Clinical Pharmaceutical Development, Jakarta, 2008, page 11.

${ }^{14}$ Act No. 8 of 1999 on Consumer Protection Article 1

${ }_{15}$ Nasution Az., An Introduction to the Consumer Protection Law, Diadit Media, Jakarta, 2011 page 3.

${ }^{16}$ Kristiyanti, Celina Tri Siwi, Law of Consumer Protection, Sinar Grafika, Jakarta, 2011, page 28.

17 Act No. 8 of 1999 on Consumer Protection Article 1 Number 3
} 
and honest about the condition and guarantee goodsand / or services; d. right to hear opinions and grievances about the goods and / or servicesused; e. right to advocacy, protection, and dispute resolution efforts Consumer protection is worth; f. the right to receive guidance and consumer education; g. right hippocampus treated or serviced properly and honestly and not discriminatory; $h$. the right to obtain compensation, compensation and / or replacement, if the goodsand / or services received are not in accordance with the agreement or not asit should be; i. rights of the provisions stipulated in other laws and regulations.

Protection is one of the concept of legal protection. Referring to the opinion of M. Hadjon, conceptually the legal protection given to the people of Indonesia is the implementation of the principle of the recognition and protection of human dignity based on Pancasila and the principle of state law by Pancasila. Legal protection is an action to protect or provide aid to legal subject, using law enforcement devices. ${ }^{18}$ While consumer protection is every effort to ensure the rule of law to provide protection to consumer. ${ }^{19}$ Legal certainty is a guarantee that the law is executed, is entitled by law to obtain his/her rights and decision can be implemented..$^{20}$ Although the rule of law is closely related to justice, and the law is not synonymous with justice. General Law, binding on every person, is a leveler, while the fairness is subjective, individualistic, and not generalize.

Meaning of the rule of law is further elaborated by Jan M. Otto was quoted as saying by Sidhartha namely that the rule of law in a particular situation requires as follows: ${ }^{21} 1$ ) there are legal rules are clear, consistent and easy to obtain (accessible), issued by the state power; 2 ) the Government shall apply the legal rules consistently, submit and obey him; 3) the majority of residents in principle approved the contents of the charge and therefore adjust their behavior to the rules; 4 ) judges (judicial) are independently and impartially apply the legal rules consistently as they resolve legal disputes, and 5) judicial decision concretely implemented.

18 Philipus M. Hadjon, Introduction to the Indonesian administrative law, Gajah Mada University Press, Yogyakarta, 2011, page 10.

${ }^{19}$ Act No. 8 of 1999 on Consumer ProtectionArticle 1 Number 1

20 Sudikno Mertokusumo, An Introduction to Legal Discovery, Liberty, Yogyakarta, 2007, page 160.

${ }^{21}$ Shidarta, Law of Consumer Protection, Grasindo, Jakarta, 2003, page 85. 
Who should provide legal protection? Basically the main actors should provide legal protection is the state. The state must be present to provide both preventive and protection. International instruments underlying the government's obligation to provide legal protection is United Nations Guidelines for Consumer Protection United Nations. It is said that governments should develop or maintain adequate standards, provisions andappropriate regulatory systems for ensuring the quality and appropriate use of pharmaceuticals through integrated national drug policies which could address, inter alia, procurement, distribution, production,licensing arrangements, registration systems and the availability of reliable information on pharmaceuticals. In so doing, Governments should take special account of the work and recommendations of the WHO on pharmaceuticals. For relevant products, the use of that organizations Certification Scheme on the Quality of Pharmaceutical Products Moving in International Commerce and other international information systems on pharmaceuticals should been courage. Measures should also be taken, as appropriate, to promote the use of international nonproprietarynames (INNs) for drugs, drawing on the work done by the WHO.In addition to the priority areas indicated above, governments should adopt appropriate measures in other areas, such as pesticides and chemicals in regard, where relevant, to their use, production and storage, taking into account such relevant health and environmental information as governments may require producers to provide and include in the labeling of products. ${ }^{22}$

\section{Examining the Role of Pharmacist}

\section{Drug-related Problems}

Pharmacist todays is facing several challenges related to the problem enountered by consumer medicines. There exists two consumer medicines related problems including (i) the pharmaceutical provision of drugs; and (ii) the pharmaceutical industry involving the production and its medicine distributions. Comsumer medicines are largely the lack of information related to drug uses such

22 United Nations Guidelines for Consumer Protection United Nations, 2003, provision 61-62. 
as side-effects, drug-interaction and irrational or clinically-unjustified drug prescription. The current state of the pharmaceutical industry that dominated by the economic purposes from the stage of production, packaging, distribution and selling has tremendously disadvantaged consumer medicines in terms of the increasing costs and prices.

Mistakes or human errors in medical treatment are adverse patient events resulting from the use of drugs for the treatment of health personnel can actually be prevented. Drug-related problem asan undesirable patient experience that involves drug therapy and that actually or potentially interferes with a desired patient outcome. ${ }^{23}$ Seven distinct types of drug therapy problems have been identified that may potentially lead toan undesirable event that has physiologic, psychological, social, or economic ramification. These problems can be placed into four categories that include $24: 1$. inappropriate indication for drug use: a. the patient requires additional drug therapy. $b$. the patient is taking unnecessary drug therapy. 2. ineffective drug therapy: a. the patient is taking a drug that is not effective for his or her situation. b. the medication dose is too low. 3. unsafe drug therapy: a. The patient is experiencing an adverse drug reaction. $b$. the medication dose is too high. 4. inappropriate adherence or compliance: The patient is unable or unwilling to take the medication as prescribed

Another issue that needs serious attention related to drug uses is its side effects. Understanding the side effects of drugs are all undesirable effects that harm or potential harm to patients (adverse reactions) due to the use of drugs. The problem of drug side effects cannot be ruled out because it can cause a variety of effects in the use of drugs both in terms of economic, psychological and therapeutic efficacy. Such as the economic impact of the rising costs of medical and psychological impact on patient compliance in taking medication will result in treatment failure. Factors that cause drug side effects can be derived from a patient factors and drug factors. Patient factors such as age, genetic and disease. In pediatric patients (especially infants) metabolism system is not perfect for the possibility of side effects can be much larger, as well as in patients with geriatric

${ }^{23}$ Strand LM, et al. Drug-related Problems: Their Structure and Function, DICP Ann Pharmacother, 24(11), 1990, page 1093-1097.

${ }^{24}$ Ibid. 
(elderly) that his condition had declined. In patients with certain diseases such as liver and kidney disorders need special attention to the use of the drug because it can cause serious side effects. Factors: the nature of the drug and the drug's potential to cause side effects such as drug selection, drug usage period, and the presence of drug-drug interactions. Each drug has a mechanism and a different work so as to cause different side effects.

Drug interactions is also one of the causes of adverse events. This occurs when health workers (doctors, pharmacists, nurses) negligent in checking drugs consumed by patients, resulting in certain effects are not expected in the patient's body. Increased severity of illness of patients that can lead to death is a condition that a lot happening around the world due to drug interactions may occur between this. Drugs interaction or between drugs with food/ beverage .

The use of the drug is said to be irrational if possible negative impacts received by the patient is greater than the positive impact. The impact can be clinical impact (egg, side effects and resistance of germs), economic impact (cost unattainable because of irrational use of medicines and the treatment time is longer) and social impact (dependency of patients on the drug intervention). Criteria irrational use of drug are over prescribing, under prescribing, multiple percribing and incorrect prescribing.

Those problems faced by consumer medicines are entitled to pharmacist to prevent and/or solve it during the pharmaceutical provision in pharmacies. The role of pharmacist in protecting consumer medicine in pharmaceutical care can be summed below:

\section{Screening Recipe}

This stage identifies three requirements have been fulfilled. Administrative requirements are as follows: Name, SIP and addresses of doctors, prescription date, signature / initial of the prescribing doctor, the name, address, age, sex and weight of the patient, the use of a clear way other information. This screening is for consumer protection administrative law to ascertain whether they are eligible to receive the drug in question. Pharmaceutical suitability examining dosage form, dosage, potency, stability, incompatibility, and the old way of 
administration.Specific pharmaceutical is a form of realization of the right of consumer to obtain goods in accordance with the exchange rate and the collateral pledged. ${ }^{25}$ Clinical Considerations examine any allergies, side effects, interactions, suitability (dose, duration, number of medications, and others). If there are doubts about the prescription should be consulted with the prescribing physician to provide alternative consideration and approval as required when necessary use after notification. These three consideration is the fulfillment of the rights of consumer conducted for the amenity, security, and safety in the consumption of goods and / or services. ${ }^{26}$

\section{Preparation of the drug}

The process of preparation of drug consist of: a) compounding, an activity to prepare to weigh, mix, package and deliver on the container label. In implementing the compounding of drugs must be made a permanent procedure with attention to dose, type and quantity of drug as well as writing the correct etiquette. Business actors prohibited goods are damaged, defective or used and polluted without providing complete and correct information on goods intended 27 ; b) etiquette which should be clear and legible .Business actors are prohibited from producing and / or trading of goods and / or services which are not in accordance with the net weight, net volume or the net, and the amount in a matter of as stated in the label or the label of the goods; c) drug Packaging Delivered. Medication should be packed neatly in a package that fits so adversely. Consumer Protection Act prohibits business operators producing and / or trading of goods and / or services that: are not in accordance with the quality, grade, composition, processing, style, fashion,or particular use as stated in the label or description goods and / or service; d) delivery of Drugs. Before the drug delivered to the patient to do a final check on the fit between prescription drugs. Delivery of drugs made by pharmacist with the provision of drug information and counseling to the patient.The delivery of these drugs is an effort to fulfill the rights of consumer the right to choose the goods and / or services as well as

${ }^{25}$ Ministry of Health Decree No. 1197/Menkes/SK/X/2004 on Standards of Pharmacy Services in Hospital Article 4 paragraph (2) letter b

${ }^{26}$ Ibid., letter a

${ }^{27}$ Ibid., letter d 
goods and / or services in accordance with the exchange rate and the conditions and guarantees promise; e) drug Information. Pharmacist must provides true, clear and easy to understand, accurate, unbiased, ethical, thoughtful, and current. Drug information to patients at least include: how to use the drug, how the drug storage, treatment durations, activities and food and beverages should be avoided during therapy. The rights of information is a basic right. Error starting drug use much of the information is not clear, where the factor giver and receiver of information. Consumer has the right to correct information, clear, and honest about the condition and guarantee of the goods and / or service. Pharmacist should provide counseling, the pharmaceutical preparation, medication and other medical supplies, so as to improve the quality of life of patients or concerned to avoid a hazard misuse or use of the wrong drug. For people with certain diseases such as cardiovascular, diabetes, tuberculosis, asthma and other chronic diseases, pharmacist must provide counseling on an ongoing basis.

Consumer protection is entitled to his/her opinions and grievances be heard on goods and / or services that are used at the same time entitled to receive guidance and consumer education. Monitoring after using the medicine, the transfer of the drug to the patient, the pharmacist must carry out monitoring of drug use. These activities are implementation of the right to advocacy, protection, and consumer protection of innapropiate mediation is inappropriate.

Consumer protection is legal certainty to guarantee the consumer received his/her rights. The forms of protection provided by pharmacist are: 1. pharmacist provides consumer rights: submit a drug; 2. pharmacist ensures the fulfillment of the rights of consumer of drugs: ensuring dosage, labeling, monitoring drug; 2. pharmacist protects consumer from inappropriate drugs: prescription screening, packaging, counseling; 3. pharmacist invites consumer to increase her/his awareness of rights: to provide information about drug.

The information regarding various aspects related to drugs could be considered very important as one of the primary right of consumer medicines. Moreover, consumer medicines should be aware of its advantage (i.e. drug information) as it increses the effectiveness of the drug provision in local 
phamacies. ${ }^{28}$ The pharmacist is obliged to provide useful information in service, which are include (i) about the drug/medicine served to patients or consumer medicines; and (ii) the appropriate usage of those drugs/medicines, his/her safety and rationality (dosage and time schedules) as required by patients and the whole society. ${ }^{29}$

Providing appropriate information regarding drugs/medicines is about an activity preparing and attesting general information, suggesting independent, accurate, comprehensive and up-to-dated recomendations for patients and other consumer medicines reguire. The information would improve the succeed of such medical treatment, optimising its effects and minimising the risk of unacknowledged side effects. Additionally, by providing the information, the pharmacist is not only perpetuaringhis/her main duities yet also maintaining his/her credibilities and integrities as a professional responsible in the provision of health service, reducing mistakes and human errors in medical treatments and building a trust with the whole consumer medicines. It is now make sense to cite the idealised purpose of providing medicines for patients that can be summed out in three aspects. First, it is about to ensure the availability and the usage of those drugs rationally or clinicallu justifies and oriented to both patients as consumer medicines, medicat staffs and other who involves. Second, providing such information about drugs to patients and other medical staffs is the main duty of pharmacist. Third, pharmacist, especially who is appointed as member of pharmaceutical and medical care comittee, are also responsible to provide appropriate informaton and invlove in decision making related to drug uses.

The right of appropriate information is encouraged in order patients or consumer medicines are able to draw correctly about such medicines thus able to choose whatever s/he wants or need and avoid harms and mistakes of it. ${ }^{30}$ As we know, such a drug would give a desired effect if it was used in accodance with its purposes and usages. Patients would obtain those desired effect if they are able to comprehend those purposes and usages as informed by physicians and medical

\footnotetext{
${ }^{28}$ Notoadmodjo, Health Promotion and Behavioral Sciences, Rineka Cipta Publisher, Jakarta, 2007, page 23.

${ }^{29}$ Mohammad Anief, General Principles and Basic of Pharmacology, Gadjah Mada University Press, Yogyakarta 2000, page 126.

${ }_{30}$ Miru, Ahmadi and SutarmanYodo, Law of Consumer Protection, PT. Raja Grafindo Perkasa, Jakarta, 2011, page 41 .
} 
staffs particularly pharmacist as professional who understand the drug and its consequences. The regulation related to the rights of consumer medicines in Indonesia refers to Act of Health service, article 7 that insists everybody has the same rights to get appropriate information and education of medical treatment including drug uses. To some extent, each person also has the equal rights for information regarding his/her health condition including all medical treatments he/she received in his/her life. ${ }^{31}$ According ot Suryawati, the appropriate information should provide such objective addec by scientific explanation and comprehensive without concealing any risks and side-effects and not consisting unclear direction that potentially lead to mis-understanding and mis-treatment. ${ }^{32}$

As elaborated by Prof. Hans W. Micklitz, an expert on consumer law from Germany, there exist two general categories related to the rights of patients or consumer medicines obtaining appropriate information about the medical treatment s/he received, well-formed and non-informed consumer ${ }^{33}$ :

a. Well-informed consumer medicines are expected to have a considerable education backgrounds and adequate and independent economic resources, the two basic components that ensure them affordable for the costs of medical treatments and communicative. This type of consumer medicines are understood his/her responsibilities, with themselves related to medical treatment they received, and relatively economically non-vulnerable group; and

b. Non-informed consumer medicines are characterized by lack of such educational backgrounds with lower-middle socio-economic class and having difficulties in communication. The type of consumer require further protection and of course the state must be responsible to do so.

The important aspect in the protection of consumer medicine can be summarized in this quote,"If there are doubts about the prescription should be consulted with the prescribing physician to provide the necessary consideration and if necessary use the alternative approval after notice". Medical work carried by doctor and pharmacist actually is complementary; are hypothetical can be said that such cooperation can be a positive influence on the output of patients (patient

\footnotetext{
${ }^{31}$ Norma Sari,Right to Judicial Review of Consumer Drug Information and Implications in the Age of Information and Communication Technology. Papers on Book : Role of Information Technology and Communication Sector Support Drugs and Medication in the Protection of Patients Yogyakarta, Graha Ilmu, Yogyakarta, 2010, page 78.

32 Suryawati S., Ethics and Free Promotion OTC Limited, National Symposium on Drug-Free and Drug-Free Limited Faculty of Pharmacy by University of Sanata Dharma Yogyakarta, 2007, page 97.

33 Shidarta, Law of Consumer Protection, Grasindo, Jakarta, 2000, page 85.
} 
outcomes). Form of collaboration between physicians and pharmacist for example searching drug history information complete and accurate; provision of drug information lege artist; utilization of evidence-based prescribing; early detection of drug prescription errors; drug monitoring (improve drug safety); enhancingcost effectiveness in prescribing medications; improve knowledge and skills of each party to the satisfaction of the patient. Collaboration is not optimal can be detrimental to the patient. Oral administration of drugs that are not adapted to the nature of the drug in question pharmacokinetic potentially decrease the effectiveness of the drug and may even increase the risk of drug interactions.

\section{Problems of Medicine Distribution}

As it is known that the general marketing of the pharmacy-products divided three ways. First, marketing through doctors. Usually used for ethical products should only be consumed through a doctor's prescription. Second, the model drug marketing consumer goods with mass marketing pattern. This pattern occurs in the marketing of OTC drugs (over the counter) that it can be sold freely. Marketing of OTC drugs is done with branding activities ranging from promotion to nameplate, attach stickers, to use the mass media such as radio and television. Third, the marketing model of bulk (wholesale), i.e., sales to the hospital. This marketing model is able to kind of ethical drugs and OTC. Drug marketing cooperation between physicians with Pharmaceutical Wholesalers is not a legal relationship, because there is no agreement between them to bind themselves, physicians have no obligation to write a prescription, or sell drugs such as those offered by the Pharmaceutical Wholesalers. They provide fee/remuneration/ bonuses to doctors who wrote prescriptions or drug selling its products only by habit alone, does not provide legal sanctions but only social sanctions alone but in fact these practices will ultimately make doctors interested to prescribe medications offered pharmaceutical companies through a system detailing the Medical representatives. In the end the consumer is a party who aggrieved at the end

The role of pharmacist in the long- chain mechanism of drug consumption, but one that entrepreneurs can play a role in consumer protection. However, the role of the pharmacist is vital as they are the cutting edge businesses that deal 
directly with consumer. In a weak bargaining position when consumer is faced with so many entrepreneurs, the pharmacist to be a "keeper", to protect consumer of drugs.

However, this protection should be balanced byredress mechanism, the business actor is liable to provide compensation for the damage, pollution, and loss of consumer or from consuming goods and or services produced or traded. Compensation in the form of a refund or replacement of goods and / or services that are similar or equivalent value, or health care and / or the provision of compensation in accordance with the provisions of applicable laws and regulations and implemented within a period of 7 days after the date of the transaction. Compensation does not eliminate the possibility of criminal charges based on further evidence regarding the element of error. This mechanism does not apply if the business operators can prove that the error was a mistake consumer.

Compensation mechanism for the regulation of drugs need to be made specifically for consumer rights more secure. Business actors like pharmacies, distributors, pharmaceutical wholesalers have to run the mechanism so that consumer can be protected over drug consumption. Government as a supervisor should encourage business actors to perform its obligations and to encourage consumer to increase his/her awareness of the fulfillment of his/her rights.

\section{Conclusion}

The role of pharmacist to protect consumer medicine in Indonesia are: First, Responsible in providing quality assurance, production and quality control on the pharmaceutical industries; Second, responsible in providing drug/pharmaceutical services in public pharmacies both in hospitals, local clinics, drugstores and other medical providers by (i) providing consumer rights: submit a drug (ii) ensuring the fulfillment of the rights of consumer of drugs: ensuring dosage, labeling, monitoring drug (iii) protecting consumer from inappropriate drugs: prescription screening, packaging, counseling (iv) inviting consumer to increase her/his awareness of rights: to provide information about drug. The information 
regarding various aspects related to drugs could be considered very important as one of the primary right. Third, the role of pharmacist in the long- chain mechanism of drug consumption, is vital as they are the cutting edge businesses that deal directly with consumer. In a weak bargaining position of consumer facing with so many entrepreneurs, the pharmacist to be a "keeper", to protect consumer of drugs.

\section{References}

Anief, Mohammad, General Principles and Basic of Pharmacology, Gadjah Mada University Press, Yogyakarta, 2000.

Az., Nasution, An Introduction to the Consumer Protection Law, Diadit Media, Jakarta, 2011.

Dwi Prahasto, Iwan, 2010, Indonesian Drug Policies Are Still Not Favoring Patients: Examples of Generic Drugs, Policy Bries No. 10/August 2010, Health Services Management Centre Faculty of Medicine Gadjah Mada University, Yogyakarta.

Ernst FR, Grizzle AJ, Drug-related Morbidity and Mortality: Updating the Cost-ofillness Model. J Am Pharm Assoc 41, Washington, 2001.

Kristiyanti, Celina Tri Siwi, Law of Consumer Protection, Jakarta, Sinar Grafika, 2011.

LM., Strand, et al., Drug-related problems: their structure and function, DICP Ann Pharmacother, 1990.

M. Hadjon, Philipus, Introduction to the Indonesian Administrative Law, Gajah Mada University Press, Yogyakarta, 2011.

Mertokusumo, Sudikno, An Introduction to Legal Discovery, Liberty, Yogyakarta, 2007.

Miru, Ahmadi and SutarmanYodo, Law of Consumer Protection, PT. Raja Grafindo Perkasa, Jakarta, 2011.

Muhammad, Abdulkadir Law and Law Research, Citra Aditya Bakti, Bandung, 2004.

Notoadmodjo, Health Promotion and Behavioral Sciences, Rineka Cipta Publisher, Jakarta, 2007.

S., Suryawati, Ethics and Free Promotion OTC Limited, National Symposium on Drug-Free and Drug-Free Limited Faculty of Pharmacy by University of Sanata Dharma Yogyakarta, 2007. 
Sari, Norma, Right to Judicial Review of Consumer Drug Information and Implications in the Age of Information and Communication Technology. Papers on Book : Role of Information Technology and Communication Sector Support Drugs and Medication in the Protection of Patients Yogyakarta, Graha Ilmu , Yogyakarta, 2010.

Shidarta, Law of Consumer Protection, Grasindo, Jakarta, 2003.

YS, Hartini and Sulasmono, Pharmacy: Review and Its Related Scripts Pharmacy Regulations Includes Manuscript and Review Minister of Health Decree About People's Pharmacy, University of Sanata Dharma, Yogyakarta, 2007.

Indonesian Consumer Protection Foundation, 2012, Examining the National Drug Policy, http://ylki.or.id/2012/01/menelaah-kebijakan-obat-nasional/

Ministry of Health, Pharmacist Responsibilities of Patient Safety, Directorate of Community Pharmacy and Clinical Pharmaceutical, Jakarta, 2008.

United Nations, United Nations Guidelines for Consumer Protection, New York, 2003.

Act No. 7 of 1963 on Pharmacy

Act No. 8 of 1999 on Consumer Protection

Act No. 36 Year 2009 on Heatlh

Ministry of Health Decree No. 1197/Menkes/SK/X/2004 on Standards of Pharmacy Services in Hospital

http://www.usciences.edu/museum/secundum_artem.shtml 